\title{
THE PROBLEM OF BALLAST WATER IN MONTENEGRO PORTS AND POSSIBILITY OF ITS TREATMENT
}

\author{
Ivana Ćipranić \\ Marija Jevric \\ Goran Sekulic \\ Sreten Tomovic \\ University of Montenegro, Montenegro
}

\begin{abstract}
The problem of ballast water has been present in the world for the last hundred years, but it has grown and become more complex with the increasing intensity of overseas traffic. Introduction of various species from different parts of the world threatens flora and fauna, especially regarding small and closed seas, such as the Adriatic Sea. New species cause an interruption of the existing food chain which keeps the natural balance and purity of the sea. Many domicile organisms in the sea have been disappearing due to changes in environmental conditions, which significantly impairs the sea-water quality. This paper deals with different possible ways of sea and port protection from ballast water, starting with administrative measures, up to proposals of technologies by which those waters could be treated. The problem of ballast water is of particular concern in the Montenegrin part of the Adriatic Sea, and the protection proposal is given.
\end{abstract}

Keywords: Adriatic Sea, ballast water, marine protection, water treatment

\section{INTRODUCTION}

Various human activities, whether on land or on the seashore, consequently lead to a violation of the natural balance of the sea bottom and the shore itself. There are a wide spectrum of activities which negatively affect natural conditions of the sea. Those are: sailing, oil platform placement, uncontrolled discharge of used and industrial waste waters, illegal construction, etc. These activities can contribute to the appearance of various pollutions, both on land and in the sea. As a result, the input of nutrients increases, along with the amount of sediments, pathogens, non-biodegradable toxic substances, radio-active substances, oil, and different kinds of waste. A special problem in the majority of seas is the emergence of new species in them, both plants and animals. With their appearance, the violation of the previously established natural balance occurs, wherein new species are usually those that push away or completely destroy original ones, usually spreading new diseases in the sea [3]. It is necessary to emphasize that these new species are most commonly related to the presence of the so-called "red tide" and other algal bloom, especially in big sea ports. The origin, i.e. the source of new species, is most frequently ballast water from ships (this work pays special attention to it) but it could also be the production of new channels as the sea confluence, or, for example, some projects related to the improvement of fostering of new fish species.

\section{BALLAST WATERS}

Ballast water, as its name suggests, is meant to increase ship stability, and by that, to increase the safety of the sail.

Ballast water was introduced into the practice of sailing about 160 years ago, when the first ship with a double bottom was built. Before that, some firm elements, made of cement or lead for instance, were used as an extra load for supporting balance or stability (in fact, this method is still used on smaller watercrafts). Nowadays, large ships use ballast water because without it, it would be impossible to sail safely. The ballast water is pumped out in the starting port, where the load is 


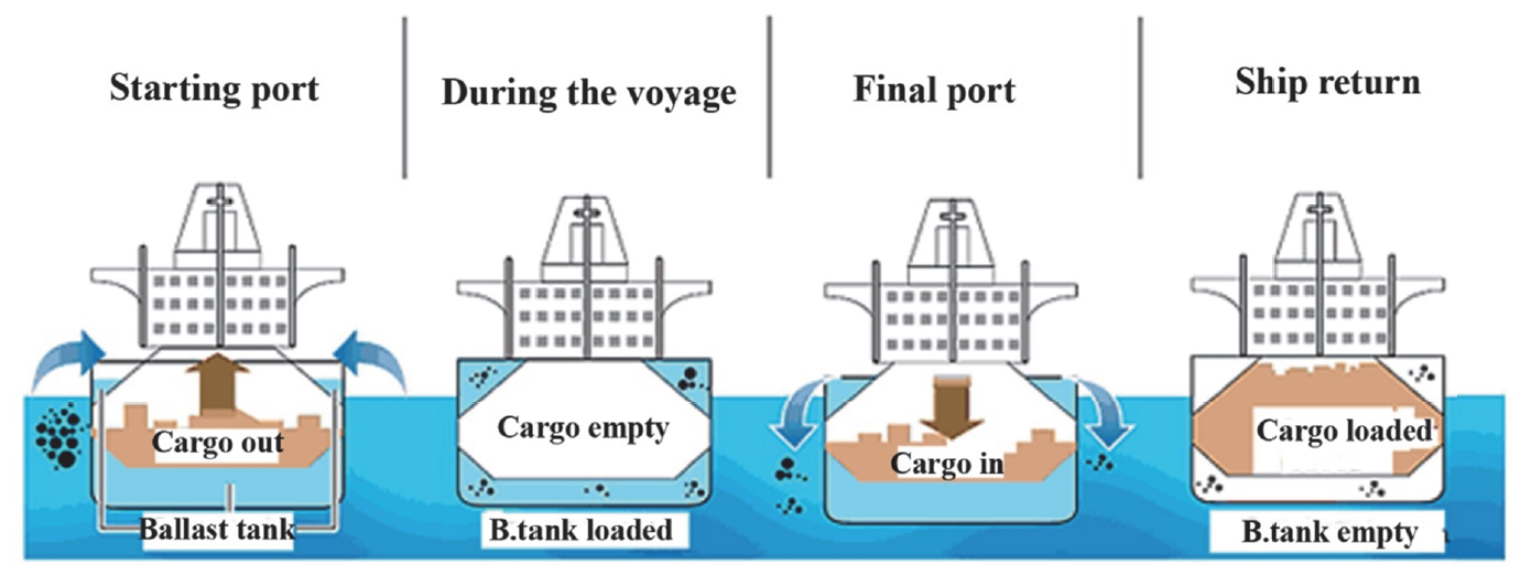

Fig. 1. Loading and discharge of ballast water [15]

being embarked and the waters' role is shifted to the load transported by the ship (Fig.1) There are various ways of ballast water distribution on boats, depending, above all, on the purpose of the ship. Usually, the water is placed in special reservoirs located on the sides of the ship. New-generation tankers, with double hull, also have these reservoirs situated under the transported cargo. They need to have sufficient volume to enable safe sailing of the ship.

\section{THE INFLUENCE OF BALLAST WATER ON THE ECOLOGICAL BALANCE IN THE ADRIATIC}

In 1903, when Asian phytoplancton alga Caulerpa appeared in the North Sea, it was noticed that the ballast water transported between various seas and its pumping out may result in migration of different forms of organisms. This also indicated that the natural balance in the water can be disturbed by ballast water discharge [4]. When gathering sea water as ballast, local organisms are also taken, and many of them survive on the ship until they are pumped out into the water. In the past, this problem was not paid much attention until it was noticed that the effects of this migration can be negative. Strong development of maritime transport brought enormous amounts of transported ballast water, and thus, a much greater possibility of species migration. Today, it is estimated that annually, 3-7 billion tons of ballast water is transported in the world, and with it, more than 7,000 various species of animals and plants are migrated [21].

As it can be seen in Figures 2, 3 and 4, the amount of ballast water discharged by the Montenegrin shore, i.e. near its ports, in 4 years' time is within the range of some 3-10 billion tons. While it is still less than in most of the endangered zones of the Mediterranean Sea, it is enough to call for paying more serious attention to this matter, considering the position of the Montenegrin coast and possible effects.

Data about the import of foreign life forms in ballast water into the Adriatic Sea are not reliable, as the Adriatic is one of the richest seas in number of fish species. But at the same time, only a small species population is represented. Besides that, the Adriatic is a warm, shallow and closed sea with slow sea current changes. One of the visible and known consequences of ballast water discharge is the so-called "sea blooming", or the reproduction of Caulerpa taxifolia, a plant which has been transported from tropical seas into the Adriatic, where it is able to survive thanks to mutation and fast expansion, creating a grass carpet on sand, silt, or stone, the kinds of bottoms the Adriatic is made of. This plant causes an interruption of the existing food chain that has sustained the natural balance and purity of the Adriatic, because many maritime organisms disappear as a result of the environment change and the violation of sea water quality.

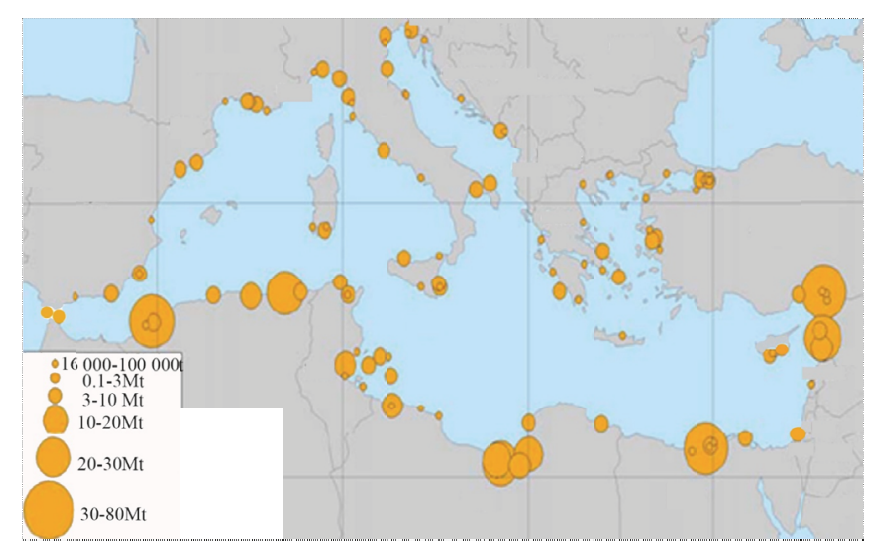

Fig. 2. Ballast water discharge at Mediterranean Sea in years 1999 - 2005 [19]

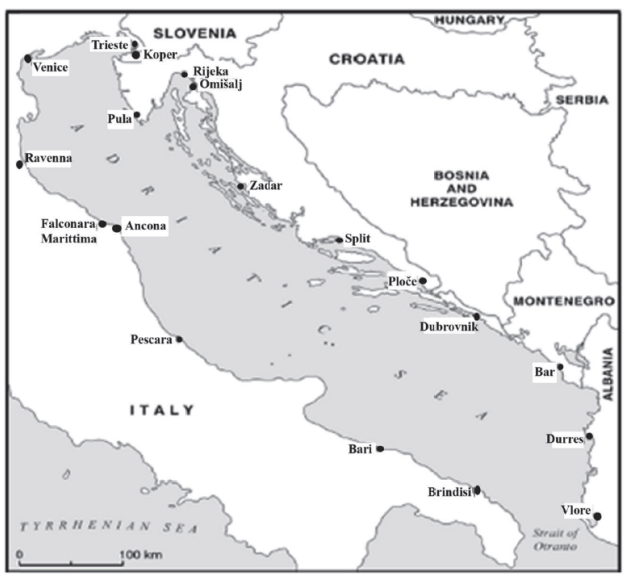

Fig. 3. Adriatic Sea, main ports [10] 


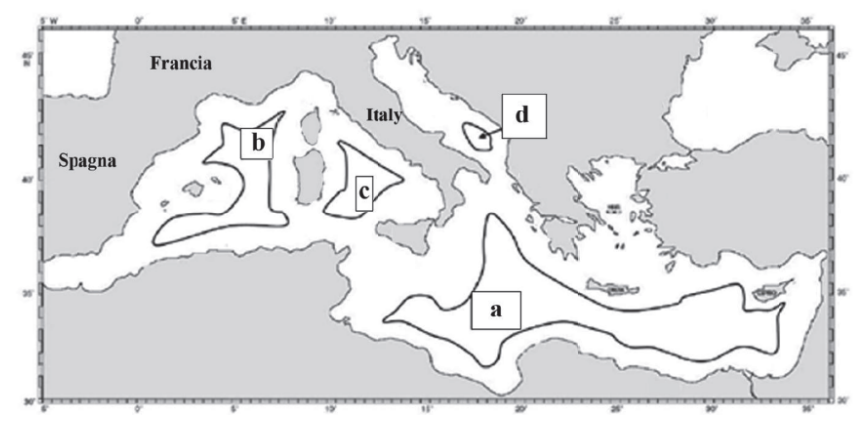

Fig. 4. Areas in Mediterranean Sea for Ballast Water Exchange [11]

The International Maritime Organization (IMO, specialized UN organization) has adopted the Convention on the Prevention of Marine Pollution by Dumping of Wastes and Other Matter (13.02. 2004.), according to which all ships are supposed to execute the exchange of ballast water at a distance of 200 nautical miles from land, and at a depth higher than $200 \mathrm{~m}$, so they can sail into the port with clear ballast. This Convention entered into force on 8th September 2017 [7].

Montenegro didn't have a legal solution to the ballast water issue, even though this problem was discussed and concern was expressed. A series of international contracts, such as: London Convention on the Prevention of Marine Pollution; OPRC convention (on oil pollution preparedness, response and cooperation) and its following Protocol to hazardous and noxious substances; International Convention for the prevention of pollution from Ships (MARPOL convention); Protocol of Barcelona Convention for the protection of the Mediterranean have been ratified and their implementation is being supervised by IMO. Also, Montenegro is a participant in two sub-regional projects concerning the protection of the Adriatic Sea. The first project relates to the annunciation of the Adriatic as a particularly sensitive maritime area in accordance to resolutions and decisions of IMO. It predicts introducing measures for the protection of the maritime ecosystem of the Adriatic, which, besides other things, will specifically regulate the exchange of ballast water. The project is in the final adjustment phase on the regional level, after which its consideration will be followed by the governments of the countries in the Adriatic region. The second project refers to the measures associated and regulated by the exchange of ballast water according to the previous project. This is a perennial project helped by the reference organizations (IMO, UNEP, Regional Marine Pollution Emergency Response Center for the Mediterranean Sea/REMPEC) [8], and its goal is to create a Mediterranean strategy which addresses the transfer of hazardous aquatic microorganisms and pathogens through the exchange of ballast ship water and sediments. [17] Being conscious of the importance of this issue, the Adriatic countries approached the common EU project named BALMAS (Ballast water management for Adriatic Sea protection), which lasted from November 2013 to March 2016 and resulted in adopting the strategy and management plans in all the countries participating in the project (Italy, Slovenia, Croatia, Bosnia and Herzegovina, Albania, and
Montenegro). This project assumes ballast water control in 12 Adriatic ports (in Montenegro, the ballast water is controlled in the Port of Bar) [6].

Being conscious of the fact that the Adriatic Sea is being sailed on more and more, no matter whether by cargo or cruise ships, yachts, or domicile inhabitants' watercrafts, the countries surrounding the Adriatic have advised this manner of ballast water discharge into their parts of Adriatic and have marked the sea itself a particularly protected marine area. It must also be noted that Croatia forbids the exchange of ballast water in their part of Adriatic. After adopting the Guidance on Ballast Waters Management, unauthorized ballast water exchange in their part of Adriatic is controlled by monitoring the entrance, speed, course, and port of anchoring of some tankers. However, this also poses the question as to where the ballast water of ships sailing into the Croatian part of the sea can be discharged, once it is prohibited in there. The Montenegrin part of Adriatic is the first stop where it could be done. It should be emphasized that the Montenegrin government has adopted a law on marine protection from pollution from watercraft objects. A significant part of this law is devoted precisely to ballast water, and the solutions proposed are in accordance with positive European experience concerning that issue.

The Bay of Kotor, which represents a unique natural entity and tourist attraction in the last few years, has become a regular destination for anchoring of big ships - cruise ships in particular. Keeping in mind that the average ballast capacity of these ships is 3,000 cubic meters, it cannot be denied that this can pose a substantial threat to the already sensitive bay of Kotor. There is no control system of ballast water upon cruise ship arrival, nor is it mandatory to give any report on possessing systems for its treatment. The expected changes of the Adriatic Sea sailing directions and the growing volume of so-called yachting tourism increase the risk of the entrance of hazardous foreign species.

In order to protect the Montenegrin part of the Adriatic Sea, the first step should certainly be determining the zero state in ports where cargo and cruise ships are anchoring, and based on that, adopting the required measures of protection.

\section{POSSIBLE TECHNIQUES FOR BALLAST WATER TREATMENT}

There are numerous techniques that can be used to minimize and prevent the entrance of various aquatic organisms with ballast water [1], [9], [14], [16]. The most efficient way is ballast water processing, which can be performed when filling ballast tanks, during voyage, during ballast discharge, or after shifting into the system for ballast storage on land. The criteria required for each ballast treatment are: it has to be safe (for both the ship and crew), it has to be acceptable for the environment (i.e. it should not cause more environmental damage than benefits); it has to be applicable (on ship design and on the procedure); it has to be economically justified and biologically efficient (in the sense of removing, destroying or, 
by some other influence, decreasing marine organisms and pathogens in ballast water) [9].

The most basic and, at the same time, the most efficient way which would prevent the expansion of undesirable organisms transported in ballast water would be prohibition of ballast water discharge into ports. In that case, ballast water would be pumped out into special ballast tanks situated in ports or beside them. That option includes further mechanical, thermal, chemical, and radiation treatment of ballast water (if necessary) intended to destroy any organisms in it (Fig. 5). However, this solution is, primarily, quite expensive and requires large space in ports. There should be reservoirs built in ports for collecting ballast water, and this water should be treated through mentioned phases. One of the options is that the purifying plants could also be installed on the ships, but that is an even more expensive solution [9]. In an attempt to solve this problem, some suggestions have appeared to exchange ballast water on the open sea, where there are less endangered maritime life forms and where the foreign coastal organisms would hardly survive [2],[16]. It is wellknown that organisms from the open ocean cannot survive in coastal waters and their specific conditions. However, this suggestion has a basic disadvantage; it can be efficient only in ocean sailing, while for the conditions of sailing in smaller and closed seas, such as the Adriatic, where routes are close to the shore, it is not a viable solution [9]. This method is prescribed and used in America and Australia, where all the ships need to exchange ballast water in the ocean, and then a check is performed in the ports to verify that the exchange has been carried out, which is easy to identify because there is a huge difference in species from the open ocean and those from coastal areas [16].

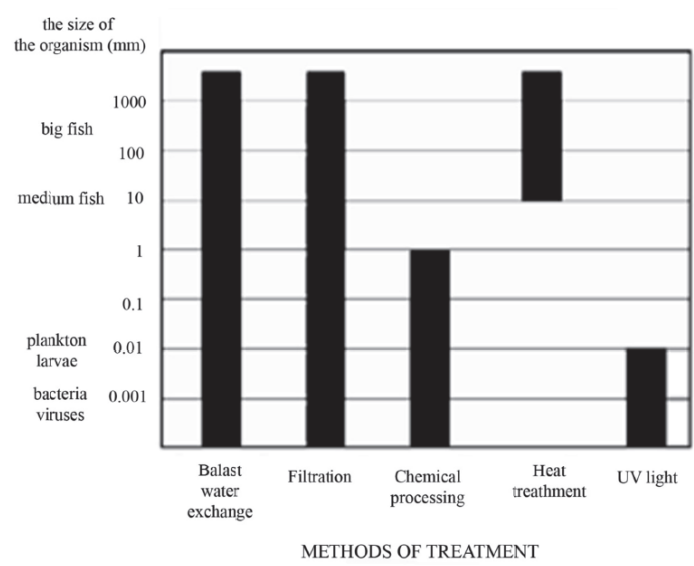

Fig. 5. Possible methods of ballast water treatment and possibility of changes depending on the size of organisms in the ballast water [1]

The thermal method seems very acceptable [12], as it makes it possible to use the waste energy from cooling ship's diesel engines. Two systems are possible for thermal treatment of ballast water. They are based on water circulation in open or closed circle. Thermal treatment of ballast water by circulation in the open circle is based on rinsing of ballast water supported by heating. Processing of ballast water by UV radiation, ozone, hydrogen peroxide, biocides, and filtration [13] are rather theoretical solutions, as the data on the optimal ratio of the most efficient method, the factory size and energy spending, the starting price of building it, as well as the expenses of the operation and maintenance is still missing. The circulation circle means no ballast discharge, i.e. complete processing of the ballast water taken from the starting port is performed inside it. The processing in closed circulation can be performed according to biological criteria of short and medium exposure of organisms to heating [16].

A brief evaluation of ballast water treatment methods is shown in Table 1 , where N means unknown, 1 - unacceptable, 2 - bad, 3 - partly acceptable, and 4 - acceptable method.

Tab. 1. Evaluation of ballast water treatment methods [9]

\begin{tabular}{|c|c|c|c|}
\hline Treatment method & Safety & $\begin{array}{c}\text { Biological } \\
\text { efficacy }\end{array}$ & $\begin{array}{c}\text { Environmental } \\
\text { friendliness }\end{array}$ \\
\hline Filtration & 4 & 1 & 4 \\
\hline $\begin{array}{c}\text { Hydrocyclone } \\
\text { separation }\end{array}$ & 4 & 1 & 4 \\
\hline Centrifugal separation & 4 & 1 & 4 \\
\hline UV radiation & 4 & 2 & 3 \\
\hline Ultrasound & 3 & 2 & 3 \\
\hline Thermal treatment & 3 & $2-3$ & 4 \\
\hline Biocides & 2 & 3 & 3 \\
\hline Ozonation & 2 & 1 & $\mathrm{~N}$ \\
\hline Pulsed plasma & 3 & $\mathrm{~N}$ & 3 \\
\hline Deoxidation & $\mathrm{N}$ & 2 & 3 \\
\hline Coating tanks & 3 & 1 & \\
\hline $\begin{array}{c}\text { Combined methods: } \\
\text { hydrocyclone } \\
\text { separation/UV } \\
\text { radiation }\end{array}$ & 4 & 3 & \\
\hline
\end{tabular}

The practice has shown that none of the ballast water treatment methods alone is efficient enough to remove all unwanted species of organisms out of ballast reservoirs. That is why the combination of different methods has been suggested as the most effective solution (Fig.6). Generally, the proposed treatment procedure has two levels: primary processing, during which larger organisms and particles are removed, and secondary processing, which aims at removing smaller organisms [9], [16].

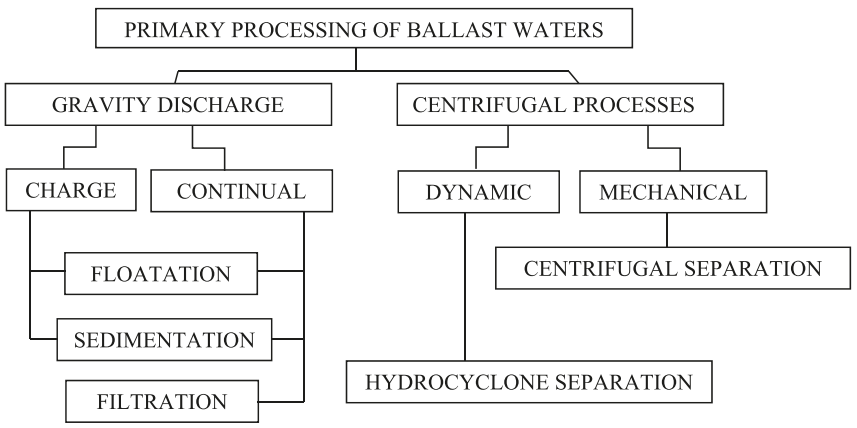

Fig. 6. Overview of possible processes of primary ballast water processing [2] 


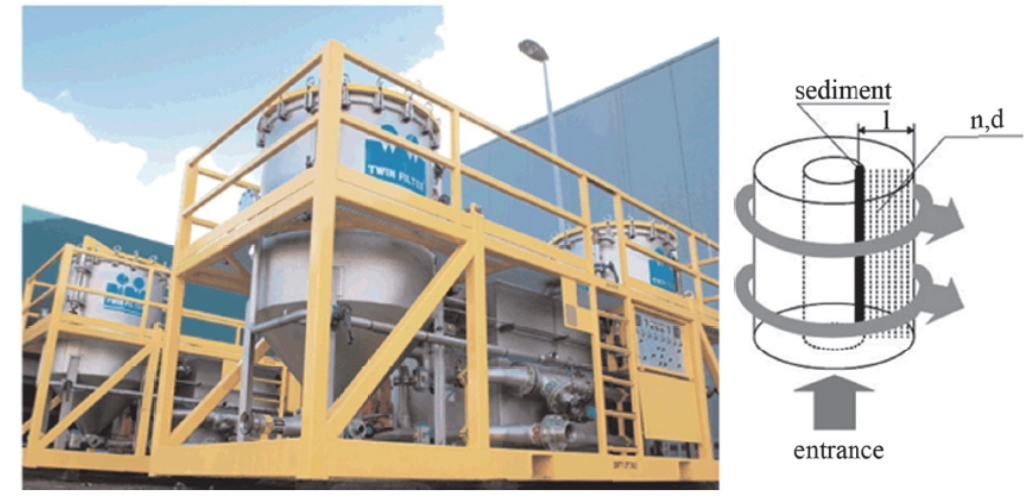

Fig. 7. Scheme and pictures of filter for ballast water treatment [16] is possible, and it requires developing the technology of processing ballast water on ships. Until then, the problem can be eased by the measures of national legislation and regional cooperation among all the countries in the Adriatic region.
The primary methods remove larger organisms and sediments, thus preparing the ballast for further processing using other methods. With centrifugal processes, the effect of separation of harder particles is even 10,000 times greater when compared to the gravitational process (Fig.7). Of all the possible methods of primary processing, the greatest effect is achieved using automatic auto-purifying filters and hydrocyclone separators, due to their appropriate dimensions, direct attachment to ballast water systems, automatic work, and simple maintenance in practice. The process of filtration continually implemented through permeable grids for liquid and solid phases (of the diameter of particles smaller than the diameter of grids) is particularly simple and effective [1], [12].

This process can be performed even during the discharge of ballast reservoirs. The advantage of water filtration during their charge is that the filtered organisms remain in their natural environment. If the ballast water is filtered during reservoir discharge, it is essential to properly put off the filtered dead organisms.

The filtration equipment is still quite expensive, both to purchase and for ship assembly. What is more, its price is growing due to the reduced size of microorganisms that should be filtered. That is the basic disadvantage of this method which prevents its unconditional recommendation. But the new legal regulations about marine protection will force many ship owners to apply this treatment, in spite of its high price.

\section{CONCLUSIONS}

Distribution of hazardous organisms with ballast water from the far seas increases threats to the ecological system of the Adriatic Sea, especially in the Montenegrin part. This endangers the survival of various ecosystems, as well as of many different branches of industry in coastal areas, especially tourism as the major resource. Keeping in mind that ballast water is a necessary element of ship's safety, and that without maritime transport, world goods exchange is impossible - the solution to this problem must be achieved in a techno-economic way. A long-term solution for this problem specific to the Adriatic Sea and part of the Montenegrin coast
1. Albert R., Everett R., Lishman J. and Smith D. (2010): Availability and efficacy of ballast water treatment technology: background and issue paper. Information report to Scientific Advisory Board, EPA.

2. Balaji R., Yaakob O. (2011): Emerging ballast water treatment technologies: a review. Journal of Sustainability Science and Management 11(1): 126-138.

3. Drake J M., Lodge D. M. and Lewis M. (2005): Theory and Preliminary Analysis of Species Invasions from Ballast Water: Controlling Discharge Volume and Location. The University of Notre Dame.

4. Fileman T., Vance T. (2010): Ballast water: a question of balance. Marine Scientist 33: p. 22-25.

5. http://globallast.imo.org/poster4_english.pdf

6. http://www.balmas.eu

7. International Maritime Organization (2005): Ballast Water Management Ballast Convention International Convention for the Control and Management of Ships' Water and Sediments. London, p.138.

8. IMO/UNEP (2004): Regional Information System. Part C: Databanks and Information Services. Section 2: List of Alerts and Accidents in the Mediterranean. Retrieved from: http://www.rempec.org

9. Kurtela Ž., Komadina P. (2010): Application of Hydrocyclone and UV Radiation as a Ballast Water Treatment Method. Traffic and Environment (Ecology), Dubrovnik, Croatia.

10. Lušić Z., Kos S. (2006): The Main Sailing Routes in the Adriatic. Naše more: Journal of marine sciences, pp. 198205, ISSN 0469-6255

11. Markovina R., Blagojević B., Ban D. (2007): "Druzhba adria" project - managing ballast water problems. Naše more: Journal of marine sciences, vol.54, No.5-6. 
12. Mountfort D, Dodgshun T, Taylor M (2001): Ballast water treatment by Heat-New Zealand Laboratory \& Shipboard trials. First International ballast water treatment R\&D symposium. Proceedings, pp 45-50. Retrieved from http://globallast.imo.org/wp-content/ uploads/2014/11/Mono5.pdf

CONTACT WITH THE AUTHORS

13. Review of treatment options available. (2003) General background on management and treatment options, Report No. 13, Department of Agriculture, Fisheries \& Forestry - Australia, www.affa.gov.au, Commonwealth of Australia.

\author{
Ivana Ćipranić \\ e-mail:ivanacipranic@yahoo.com
}

University of Montenegro

Faculty of civil engineering

Cetinjski put. b.b. Podgorica 382 Podgorica

MONTENEGRO

14. Rigby G. (2004): Ballast water treatment technology; choosing the best options. Proceedings of Conference on the Control and management of ship's ballast water and sediments.

15. Singh B. (2017): Everything You Wanted to Know About Ballast Water Exchange and Management Plan. Retrieved from: https://www.marineinsight.com/maritime-law/everything-you-wanted-to-know-about-ballast-water-exchange-and-management-plan/

16. Tsolaki E., Diamadopoulos E. (2010): Technologies for ballast water treatment: a review. Journal of Chemical Technology \& Biotechnology, Vol. 85, No. 1: 19-32.

17. UNEP (2005): Mediterranean strategy on ships' ballast water management.

18. Voigt M., Gollasch S. (2000): Ballast Water: The Latest Research and Methods of Treatment. 3rd Annual conference "Managing Environmental Risk in the Maritime Industry", London, UK.

19. www.pfst.unist.hr

20. www.lr.org/en/ballast-water-management/

21. www.researchgate.net/publication/301821711_Effect_of Ballast_Water_on_Marine_and_Coastal_Ecology 